\title{
O FENÔMENO DO SUPERENDIVIDAMENTO DO CONSUMIDOR NO CONTEXTO DE DESIGUALDADE SOCIAL NO BRASIL
}

\author{
Dennis Verbicaro* \\ Luiza Correa Colares Nunes ${ }^{* *}$
}

SUMÁRIO: Introdução; 2 A desigualdade social no Brasil: 2.1 A desigualdade oriunda do sistema capitalista; 2.2 A desigualdade acentuada no contexto brasileiro; 2.3 Desigualdade e divisão de classes; 3 O problema do superendividamento no Brasil; 3.1 Conceituação do termo; 3.2 Contexto brasileiro e principais causas; 3.3 Efeitos sobre os indivíduos e a sociedade; 40 superendividamento dentro do contexto de desigualdade social no Brasil; 4.1 Análise a partir da realidade de segregação em classes sociais; 4.2 A tutela jurídica dos danos ao consumidor; 4.3 A influência do meio sobre o consumo; 4.4 Controle pré-contratual e o princípio da transparência; 4.5 A influência da indústria cultural; 4.6 Avaliação comportamental dos consumidores a partir do contexto de classes; 5 Conclusão; Referências.

RESUMO: O presente artigo, pelo método dedutivo, por meio de pesquisa teórico- bibliográfica nacional e estrangeira, objetiva compreender as principais causas e consequências do superendividamento dentro do contexto de desigualdade social no Brasil, de modo a compreender que o mesmo não incorre em um problema unicamente da classe baixa, mas de toda a sociedade. Nesse sentido, objetiva-se também a compreensão dos aspectos comportamentais dos indivíduos e o afastamento da responsabilidade exclusiva do ente sobre a condição de superendividamento. Em conclusão, o trabalho propõe alterativas, como o aprimoramento dos deveres informacionais do fornecedor, o controle da oferta do crédito e a promoção de educação financeira ao consumidor.

PALAVRAS-CHAVE: Direito do consumidor; Desigualdade social; Superendividamento; Hipervulnerabilidade; Divisão de classes.

Doutor em Direito do Consumidor pela Universidad de Salamanca (Espanha), Mestre em Direito do Consumidor pela Universidade Federal do Pará. Docente da Graduação e dos Programas de Pós-Graduação Stricto Sensu da Universidade Federal do Pará-UFPA e do Centro Universitário do Pará-CESUPA. Procurador do Estado do Pará e Advogado, Brasil. E-mail: : dennisverbicaro@bol.com.br

"Graduanda em Direito do Centro Universitário do Pará-CESUPA e integrante do Grupo de Pesquisa "Consumo e cidadania" (CNPq), Brasil. 


\title{
THE PHENOMENON OF CONSUMER'S HYPER-INDEBTEDNESS WITHIN THE CONTEXT OF SOCIAL INEQUALIT Y IN BRAZIL
}

\begin{abstract}
Current Brazilian and foreign deductive, theoretical and bibliographical research investigates the main causes and consequences of hyper-debts within the context of social inequality in Brazil. The phenomenon does not exist within lowwaged class but in all society. The paper analyzes the behavioral aspects of people and the shunning of exclusive responsibility with regard to hyper-indebtedness. Research proposes alternatives such as improvement in the supplier's information, control in credit offer and the promotion of the consumer's financial education.
\end{abstract}

KEY WORDS: Consumer's rights; Social inequality; Hyper-indebtedness; Class division.

\section{EL FENÓMENO DEL SÚPER ENDEUDAMIENTO DEL CONSUMIDOR EN EL CONTEXTO DE DESIGUALDAD SOCIAL EN BRASIL}

RESUMEN: En el presente artículo, por el método deductivo, por intermedio de investigación teórico-bibliográfica nacional y extranjera, se tiene por objetivo comprender las principales causas y consecuencias del súper endeudamiento dentro del contexto de desigualdad social en Brasil, de modo a comprender que esto no ocurre en un problema únicamente de la clase baja, sino de toda la sociedad. Se tiene por objetivo, también, la comprensión de los aspectos comportamentales de los individuos y el alejamiento de la responsabilidad exclusiva del ente sobre la condición de súper endeudamiento. En conclusión, el estudio propone alterativas, como el perfeccionamiento de los deberes informacionales del suministrador, el control de la oferta del crédito y la promoción de educación financiera al consumidor.

PALABRAS CLAVE: Derecho del consumidor; Desigualdad social; Súper endeudamiento; Híper vulnerabilidad; División de clases.

\section{INTRODUÇÃO}

A pesquisa tem por escopo analisar o fenômeno do superendividamento, isto é, incapacidade do consumidor de quitar dívidas atuais e futuras sem o comprometimento do seu mínimo existencial - ficando excluídas dívidas fiscais - frente a desigualdade social no Brasil. Nesse âmbito, visa entender, como esse fenômeno atinge e agrava a desproporção financeira entre as classes e, paralelamente, como a desigualdade socioeconômica favorece o superendividamento, pela própria vulnera- 
bilidade agravada dos sujeitos em razão de fatores psíquicos, sociais e econômicos.

Nessa perspectiva, o objeto de análise será, em um primeiro momento, o contexto de desigualdade social e econômica, a fim de expor a situação atual no país, para, posteriormente, expor o conceito de superendividamento, visando identificar suas principais causas na sociedade brasileira e os efeitos que gera sobre os indivíduos - para além da sua condição de "mero" consumidor, mas enquanto ser-humano, cidadão brasileiro, dotado de dignidade - e sobre a sociedade de modo geral.

Por conseguinte, será realizada a confluência das duas temáticas, a fim de finalmente analisar o tema do superendividamento dentro do contexto de desigualdade social e econômica no país, de modo a problematizar essa relação e analisá-la, no intuito de entender a incidência do fenômeno sobre as diferentes classes sociais, e, portanto, se este agrava a disparidade.

Dessa forma objetiva-se a análise do contexto de segregação em classes sociais, a fim de compreender os variados caminhos que podem levar ao superendividamento, e, portanto, demonstrar que o mesmo não é um problema exclusivo das classes mais baixas, ou seja, da pobreza, mas uma problemática macro. A partir disso, busca-se o entendimento dos aspectos comportamentais em cada classe social, tanto quanto a propensão e causas que levam esses indivíduos à condição de superendividados, como a maneira que se comportam ao encontrar-se nessa situação.

Há, portanto, dentro dessa perspectiva, a necessidade de afastamento da responsabilidade unicamente do indivíduo superendividado sobre sua condição, mas compreender enquanto uma problemática que atinge toda a sociedade, uma vez que é impossível separar a influência do meio socioeconômico sobre os entes.

Nesse interim, demonstra-se de extrema necessidade a análise do meio realidade social e econômica brasileira - para melhor compreensão da expressão do superendividamento aqui analisado, no intuito de verificar as reais causas do mesmo no país e de que maneira tem atingido a sociedade como um todo, bem como agravado ainda mais a desproporção econômica, além dos efeitos sociais e psíquicos sobre os entes.

Há também a pretensão de analisar uma série de práticas - falta de informação de qualidade, práticas abusivas pelos fornecedores, disponibilização irresponsável do crédito - que pode levar ao superendividamento e, portanto, buscar responder de que forma o superendividamento dentro do Brasil tem relação direta 
com a organização social, econômica e também cultural - avaliação da indústria que veicula e constrói necessidades irreais, mas também da falta de educação financeira disposta aos indivíduos - do país e a partir disso, de que maneira essa situação pode ser minorada.

O trabalho faz uso do método dedutivo, a partir de pesquisa teórico-bibliográfica de fontes nacionais e estrangeiras e qualitativo, a fim de entender a natureza do fenômeno estudado, sob uma perspectiva transdisciplinar do consumo, nos aspectos econômico, social e psicológico, avaliando medidas que minimizem o impacto negativo da relação explorada.

Por fim, o trabalho propõe alternativas, como o aprimoramento dos deveres informacionais do fornecedor, o controle da oferta irresponsável do crédito, a obrigação do Estado de fomentar a educação financeira do consumidor, identificação da vulnerabilidade comportamental do consumidor superendividado e a consequente regulação normativa do assédio de consumo, sobretudo quando seus efeitos se revelam mais nocivos em relação à população de baixa renda.

De modo que não mais se pode colocar o consumidor como único ou principal responsável em suas relações de consumo, já que esse integra uma rede de relações e práticas, sob as quais se encontra sempre do lado mais frágil, deixando, portanto, de ser um problema do indivíduo, mas de toda a coletividade, chegando a atingir o país em escala multidisciplinar. Não restando dúvidas sobre a relevância do tema, o qual por demasiado tempo foi e tem sido subestimado e entendido enquanto problemática meramente individual.

\section{A DESIGUALDADE SOCIAL NO BRASIL}

É de suma importância para construção da pesquisa, no intuito de atingir o objetivo estudado, avaliar a realidade brasileira, no que tange a forte desigualdade social e econômica no país, a fim de entender, posteriormente, de que forma o modo de organização socioeconômica reflete enquanto meio propício ao fenômeno do superendividamento. 


\subsection{A DESIGUALDADE ORIUNDA DO SISTEMA CAPITALISTA}

A partir do contexto histórico que transita desde as monarquias até a realidade de Estado democrático é construída uma estrutura que possibilita e explica a existência da desigualdade social e econômica.

O sistema capitalista tem como um dos principais discursos, a ideia de isonomia e a possibilidade de ascensão socioeconômica pelos méritos individuais dos sujeitos, e por sua vez, o trânsito entre as classes sociais, de modo que, se um cidadão tem o objetivo de ascensão social no modelo de "qualidade de vida" proposto pela ideologia burguesa, lhe bastará o trabalho e a força de vontade para alcançar esse novo status social.

Há, porém, premissas equivocadas nessa concepção de igualdade, isso porque em países marcados pela desigualdade social, como o Brasil, essas variáveis citadas não são suficientes para permitir a mobilidade social dos cidadãos de baixa renda, pois a pobreza interfere diretamente na estabilidade familiar, no acesso à educação qualificada e, por conseguinte, na possibilidade de ascensão pelo trabalho, bem como na própria distribuição da riqueza do país.

O capitalismo propaga o ideal de que as pessoas teriam a capacidade de sair de uma situação de desigualdade, a qual, na realidade, é pressuposto do próprio sistema. Sobre isso, Karl Marx ${ }^{03}$ afirmava que na verdade, era a principal motivação do sistema capitalista, ter cada vez mais a renda concentrada nas mãos da minoria (burguesia), em desfavor da maioria (proletariado) e, nesse sentido, que a desigualdade não poderia ser desatrelada desse modo de produção injusto e desigual.

Apesar da análise de Marx sobre o sistema capitalista ser referente ao modo de produção industrial do século XIX, e que desde então houve mudanças e evoluções no modelo de produção, não deixa de se manter atual no contexto das sociedades de consumo contemporâneas.

Sobre essa relação, Thomas Piketty ${ }^{04}$ entende a partir de seus estudos e verificações gráficas, que a maior causa da desigualdade dentro do sistema capitalista é o próprio capital, de modo que, a taxa de rendimento do capital precede sobre a taxa de crescimento econômico, o que acarreta a sobreposição da riqueza sobre o trabalho, gerando um danoso desequilíbrio na distribuição da renda.

Portanto, sobre uma análise e outra, reforça-se a inevitável presença da

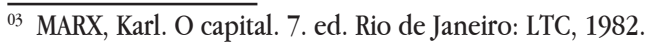

${ }^{04}$ PIKETTY, O capital no século XXI. Rio de Janeiro: Intrínseca, 2014. 
divisão desproporcional da renda, cabendo, não a discussão da mesma, mas seu grau de expressão na sociedade, sobretudo no Brasil, haja vista que, outros Estados, a exemplo da Noruega e do Reino Unido - índices GINI (indicador de disparidade de renda) em torno de 0,250 e 0,310 respectivamente ${ }^{05}$ - que também adotam o sistema capitalista, conseguem organizar-se de maneira tal que a desigualdade torna-se mais amena, e, portanto, a desproporção na divisão de renda entre as classes é mais branda.

\subsection{A DESIGUALDADE ACENTUADA NO CONTEXTO BRASILEIRO}

Em contraponto, a realidade social, econômica e política do Brasil só faz agravar o problema da desigualdade dentro do território - considerado em 2017 o décimo país com o maior índice de desigualdade, apresentando o índice GINI por volta de $0,520^{06}$. Exemplo dessa intensificação, é a grave corrupção presente na política do país, a qual, interfere diretamente na administração do erário, prejudicando a economia e as condições sociais, já que, ao invés de a renda ser convertida em saúde, educação, mobilidade urbana e outras necessidades/direitos básicos dos cidadãos brasileiros, dá-se outra destinação, divergente do interesse coletivo. Contexto sobre o qual, o Brasil, apesar de seu tamanho e riquezas, não consegue se desenvolver, já que os rombos nos cofres públicos e a má gestão protagonizam crises econômicas no país, as quais geram desemprego, inflação, encarecimento dos produtos essenciais, o que agrava ainda mais a desigualdade no país.

Ademais, a segregação social e o preconceito também contribuem no sentido em que as oportunidades se concentram naqueles que já possuem estabilidade financeira, de tal modo que para parcela mais pobre da sociedade não se destinam as mesmas oportunidades, não só por conta da negligencia estatal, mas também, a partir de uma carga histórica de discriminação, que atinge as minorias marginalizadas.

Aqueles que já têm oportunidades e condições por pertencerem a parcela que configura principalmente a classe alta (A) da sociedade, seguem acumulando-as, e aqueles que não as possuem, continuam sem vislumbrar possibilidade de ascensão socioeconômica, pois apesar de nutrirem a possibilidade de tomar decisões e fazer suas próprias escolhas, teriam sua condição social influenciada pela condição eco-

\footnotetext{
05 PORDATA. Base de dados Portugal Contemporâneo: Fundação Francisco Manuel dos Santos, 2017.

${ }^{06}$ CORREA, Marcelo. Brasil é o $10^{\circ}$ país mais desigual do mundo. O Globo, 2017.
} 
nômica, levando-os a decidir com base em necessidades e não com base uma autonomia autêntica da vontade, ou seja, teriam uma liberdade fictícia nesse quadro de desigualdade.

Apesar da existência de algumas políticas públicas, que visam amenizar essa problemática, as mesmas ainda não se mostram suficientes. Exemplo disso, é o sistema de cotas - que busca fornecer à parcela marginalizada da sociedade, a possibilidade de adentrar no ensino superior - o qual, por ser uma medida paliativa e não de solução causal, acaba por não conseguir resolver o problema da educação no país, haja vista que, visa incluir aqueles que não tiveram uma educação de qualidade, permitindo-lhes acesso às universidades, o que não deixa de ser positivo, porém não resolve o problema da educação na base do sistema.

Nessa perspectiva, tem-se que, aproximadamente $30 \%$ da renda brasileira está na posse de mero $1 \%$ da sociedade, situação que foi considerada na Pesquisa de Desigualdade Mundial 2018 ${ }^{07}$, liderada por Thomas Piketty, entre outros economistas e estudiosos, como a maior concentração do tipo, no mundo. A referente pesquisa buscou construir um banco de dados, o qual, nos permite a avaliar a distribuição desigual de renda do mundo nos últimos anos, de modo que, se tem em dimensões estatísticas que o capital sempre se inclinou no sentido de produzir níveis - cada vez maiores - de desigualdade.

\subsection{DESIGUALDADE E DIVISÃO DE CLASSES}

Ao longo da história, passamos a ter uma divisão entre as parcelas sociais, isso é, uma organização indicativa, socioeconômica, que objetiva classificar a partir da desigualdade, essas parcelas. No sentido em que, essas podem ser divididas de forma mais didática em classe alta (A); média (B) e baixa (C), isto é, a parcela mais rica, a mediana, e a mais pobre da sociedade. É claro que há ramificações dessas definições dentro de cada camada social, todavia, não cabe à pretensão analítica do texto estudá-las, mas conseguir compreender que existe uma segregação, a qual terá impacto sobre o tema do superendividamento. E que, segundo Pierre Bourdieu

$\overline{{ }^{07} \text { BORGES, Rodolfo. O }}$ Brasil tem maior concentração de renda do mundo entre o 1\% mais rico. El País, 2017. 
As diferentes posições que os grupos ocupam no espaço social correspondem estilos de vida, sistemas de diferenciação que são a retradução simbólica de diferenças objetivamente inscritas nas condições de existência ${ }^{08}$.

Isto é, além das diferenças econômicas - âmbito objetivo - existentes dentre as classes sociais, haverá nas mesmas, modos particulares de pensar o núcleo onde vivem, em virtude das nuances de cada formação, haja vista a construção geral, paradigmática, de cada sociedade, mas também os entendimentos internos decorrentes dos grupos variados em meio a coletividade. É importante analisar aspectos comportamentais - subjetivos - de cada classe, a fim de atingir o entendimento da proporção em que essas diferenças e particularidades sofrerão com as consequências do fenômeno do superendividamento.

É nesse aspecto em que compreendemos a expressão da desigualdade a partir do sistema adotado no Brasil e o seu agravo frente à realidade socioeconômica e política do país, de modo a compreender também que essa desigualdade gera uma divisão em classes, permitindo passar para análise do segundo ponto de exposição do artigo: o fenômeno do superendividamento e sua manifestação dentro do mercado de consumo brasileiro.

\section{O PROBLEMA DO SUPERENDIVIDAMENTO NO BRASIL}

No intuito de dar seguimento à pesquisa e atingir seu objetivo, isto é, analisar a expressão do superendividamento dentro do contexto de desigualdade social no Brasil, é fundamental que haja uma análise sobre o conceito, bem como as principais causas do superendividamento, e dessa forma, como tem se apresentado no país nos últimos anos.

\subsection{CONCEITUAÇÃO DO TERMO}

O superendividamento é um fenômeno complexo que tem se tornado muito presente no Brasil, isso porque, cada vez mais o assédio ao consumo, a oferta irresponsável do crédito, a negligência do Estado quanto à educação financeira do consumidor e à hipervulnerabilidade do consumidor de baixa renda, tudo tem in-

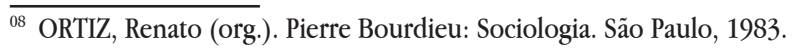


terferido no comportamento do consumidor, hoje caracterizado por uma identidade oscilante e pelo consumo compulsivo, já havendo dados empíricos a ratificar a ocorrência, como aqueles obtidos em pesquisas feitas pela Universidade Federal do Rio Grande do Sul-UFRGS, junto à Defensoria Pública do Rio Grande do Sul, que constataram que a problemática já é um fato atual e grave no país ${ }^{09}$.

Assim sendo, "superendividado" é o termo que tem sido utilizado para classificar aquele consumidor que se encontra em uma situação análoga à falência mercantil, de modo que, a jurista Cláudia Lima Marques o define enquanto "a impossibilidade total de o consumidor, pessoa física, devedor, leigo e de boa-fé, pagar suas dívidas atuais e futuras decorrentes do consumo (excluídas as dívidas com o Fisco, oriundo de delitos e de alimentos)" ${ }^{\prime 10}$.

Conceito este, bastante explicativo e específico, de maneira que o consumidor para ser considerado superendividado precisa estar sem condição alguma para quitar suas dívidas - essas decorrentes de consumo (afastando os tributos) - além de se enquadrar como pessoa física (as PJ's podem ser entendidas como em estado de falência, situação - diferente da aqui explorada - tutelada pela legislação brasileira, lei no $11.101 / 05)$, leigo e de boa-fé, isto é, ente desprovido de obrigação profissional para com a organização do crédito, e possuidor de honestidade e transparência em suas ações, excluindo situações como indébito proposital, ou quaisquer formas similares que configurem a má-fé do consumidor.

Sobre essa lógica, há ainda as definições legais internacionais, que reiteram e complementam o estudo do conceito em questão. Para a legislação norte-americana, o consumidor superendividado teria um tratamento semelhante ao disposto no Brasil para as pessoas jurídicas, situando o indivíduo enquanto em estado de falência, proporcionando a organização de suas dívidas no sentido de honrá-las com a venda dos bens disponíveis, de modo que, ainda restando débitos, se disponibiliza o perdão dos mesmos, criando uma política denominada "fresh start".

Já a legislação francesa (art. L.330-1 do Code de la Consommation) determina o fenômeno enquanto a "impossibilidade manifesta para o devedor de boa-fé de honrar o conjunto de suas dívidas não profissionais, exigíveis e vincendas" e tem tratado o problema com uma política de reeducação, isso porque, assim como a maior parte dos países europeus, a França adota um ideal mais conservador, enxer-

\footnotetext{
${ }^{09}$ MARQUES, Claudia Lima; CAVALAZZI, Rosângela Lunardelli. Direitos do Consumidor endividado: superendividamento e crédito. São Paulo, 2006.

${ }^{10}$ Ibid., p 256.
} 
gando o consumidor como o maior responsável por seus atos, e portanto, focando seu modelo de combate ao superendividamento, na educação financeira, de modo que, apesar de a mesma ser de extrema importância, tem falhas, como ignorar o fenômeno difuso do assédio de consumo, bem como por não responsabilizar as instituições financeiras pela oferta irresponsável do crédito, pois é inegável que o superendividamento tem muitas outras causas que um mero erro ou descontrole financeiro do consumidor.

Tal como afirma José Reinaldo de Lima Lopes ${ }^{11}$, "o grande desafio, é que o superendividamento ainda é tratado pela sociedade como uma questão de cunho individual, cuja solução passa pela simples execução do devedor", de forma que, tal como será falado no decorrer do presente tópico, a problemática vai além da esfera unicamente econômica ou pessoal do consumidor.

Por fim, no sentido de concluir a conceituação do superendividamento, tem-se a definição legal brasileira, a qual, apesar de ainda não dispor de um modelo de tratamento definido, trouxe a temática do superendividamento no Projeto de Lei do Senado no 283/12 - agora PL no 3515/2015, numeração definida após apreciação pela Câmera de Deputados - o qual a definiu no $\S 1^{\circ}$ do seu art. 54-A:

$\S 1^{\circ}$ Entende-se por superendividamento a impossibilidade manifesta do consumidor, pessoa natural, de boa-fé, pagar a totalidade de suas dívidas de consumo, exigíveis e vincendas, sem comprometer seu mínimo existencial, nos termos da regulamentação.

Reforçando o conceito, já explicitado, definido pela doutrinadora Cláudia Lima Marques.

\subsection{CONTEXTO BRASILEIRO E PRINCIPAIS CAUSAS}

Portanto, a partir da definição do termo, far-se-á análise do fenômeno do superendividamento dentro da realidade brasileira. Nos últimos anos, a quantidade de indivíduos e famílias superendividados têm crescido no Brasil, de forma que, assim como avaliado, passa a ser uma preocupação não apenas com o consumidor em

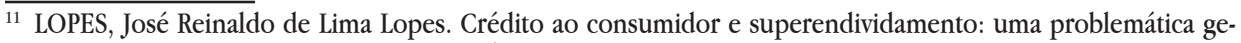
ral. Revista de informação legislativa, 1996, p. 111. 
si, mas com a realidade social e econômica do país. O disparate entre as condições econômicas cresce junto ao índice de superendividados, logo, quanto mais pessoas se endividam, menor será a distribuição da riqueza.

Os bancos, por exemplo, com altíssimas taxas de juros, agravam o problema, visando o enriquecimento e o lucro imediato, negligenciam a situação de decadência econômica com a qual colaboram, isto porque, como já citado, o problema tem se tornado tão enfático, que deixa de ser uma preocupação unicamente do direito do consumidor, mas de ordem sistêmica, econômica e social. O crescimento de endividados pode influenciar em um regresso do empreendedorismo e do consumo saudável, necessário para o movimento do mercado, afetando uma possível performance aprazível da economia brasileira e a tornando em contraponto, ainda mais crítica e prejudicial à sociedade. Sobre isso, a professora Andressa Jarletti de Oliveira alerta que

[...] as consequências geradas pela inadimplência conferem aos bancos o enorme poder, de influir na prosperidade ou insucesso da vida pessoal e da atividade profissional de seus clientes, podendo afetar, em última instância, os rumos da economia naciona ${ }^{12}$.

Logo, vale analisar fatores que são, possivelmente, as principais causas do superendividamento, a fim de expor os conceitos, uma vez que serão mais à frente explorados, no sentido de avaliar a expressão do superendividamento em meio à realidade de desigualdade social do Brasil. A partir disso, umas das, se não a principal causa do superendividamento, é a disponibilização (irresponsável) do crédito, a qual por si só, já gera riscos ao consumidor brasileiro, haja vista a realidade social, em que a maior parte da população carece de educação básica, e, portanto, educação financeira se revela uma exigência distante.

Os problemas decorrentes da oferta irregular do crédito agravam a vulnerabilidade do consumidor. As modalidades de acesso ao crédito se multiplicam, e, por sua vez, as formas de adentrar em uma realidade de superendividamento crescem da mesma maneira, haja vista que a expansão dos serviços não aumenta de modo exponencial à proteção do consumidor. Como citado, não há normas específicas a

$\overline{12}$ OLIVEIRA, Andressa. Crédito, inadimplência e os desafios para a proteção dos consumidores nos contratos bancários. Revista de Direito do Consumidor, 2015. 
fim de combater a disponibilização irresponsável do crédito, restando utilizar-se das disposições do CDC e do Código Civil (arts. 478 a 480, CC e art. 6, CDC) que versam sobre lesividade, boa-fé e onerosidade excessiva.

A fim de avaliar mais do que a democratização do crédito, mas sua variante de disponibilização irresponsável, é que se coloca em pauta as modalidades mais comuns de acesso ao mesmo, e, portanto, de fácil inclinação do consumidor ao superendividamento, sendo esses, o cartão de crédito - facilmente disponibilizado, muitas vezes dispensando comprovação efetiva de renda, além de atribuir altos juros, de modo que o Brasil tem um dos spreads bancários mais altos do mundo - o cheque especial - que configura um crédito previamente aprovado pelo banco, a fim de que, quando o cliente estiver sem dinheiro na conta corrente ou precisar utilizar mais do que possui na mesma, possa fazer uso dessa quantia, passando a ficar com o saldo negativado, situação que, além da disponibilização de crédito para um consumidor sem saldo, ainda atribui um dos mais altos juros dentre os empréstimos - e o crédito consignado - o qual, exemplifica o problema de falta de fiscalização, uma vez que, apesar da determinação de não ultrapassar o mínimo legal, ao descontar o consumidor diretamente em sua renda mensal, muitas instituições não deixam de oferecer outras formas de crédito aos clientes que já utilizam o crédito consignado, de modo a comprometer mais do que o permitido de sua renda, levando o consumidor, facilmente, a um nível extremo de endividamento ${ }^{13}$.

Não obstante, o superendividamento ainda conta com expoentes de acentuação que não estão diretamente ligados ao crédito, mas colaboram para a aquisição irresponsável deste e para o crescimento do fenômeno no Brasil. Sendo esses, o assédio ao consumo, e entende-se aqui, não apenas o consumo do crédito, mas o consumo de bens, inerente a uma sociedade capitalista, mas atenuado por um momento em que crescem as propagandas abusivas - vendendo a necessidade de aquisição de bens materiais como forma de firmar-se socialmente e atingir um estado de felicidade - a hipervulnerabilidade do consumidor, relacionada a fatores econômicos, psíquicos e sociais, e a falta de educação financeira da sociedade brasileira como um todo.

Ademais, a partir desses fatores de causa do superendividamento, é cabível

${ }^{13}$ Camille Ataíde e Dennis Verbicaro demonstram as problemáticas apresentadas, aprofundando a discussão a respeito das mesmas, a partir de sua expressão e efeitos no Brasil, em seu texto: O crédito como objeto de tensão qualificada na relação de consumo e a necessidade de prevenção ao superendividamento (ATAíDE, Camille; VERBICARO, Dennis. O crédito como objeto de tensão qualificada na relação de consumo e a necessidade de prevenção ao superendividamento. Revista da Faculdade de Direito da UFRGS, Porto Alegre, v. esp., n. 36, p. 73-89, out, 2017, p. 78). 
ter em pauta questões que contribuem dentro desse contexto, ainda mais para o fenômeno. A evolução das formas de comunicação, e há que se falar aqui, a respeito das plataformas digitais, as quais proporcionaram à atualidade uma conectividade exacerbada entre fornecedor e consumidor, facilitando por sua vez, tanto a divulgação das marcas, quanto o processo de aquisição dos bens. A propagação dos padrões estéticos e o assédio ao consumo se tornam mais agressivos e presentes no dia a dia do consumidor, tornando-se praticamente impossível a um indivíduo que utiliza plataformas digitais para o trabalho, o entretenimento e/ou comunicação, não se deparar diariamente com intensa publicidade fomentando novas necessidades artificiais de consumo.

Desse modo, a sociedade atual tem se inclinado no sentido de favorecer o "ter" ao invés do "ser", conduta que leva a uma irrelevância dos bens, o quais se tornam cada vez descartáveis, não pela sua obsolescência, mas por uma inadequação social, ou seja, por deixar de atribuir valor no âmbito da imagem, do status. Tal como expõe Lipovetsky

As indústrias e os serviços agora empregam lógicas de opção, estratégias de personalização dos produtos e dos preços, a grande distribuição empenha-se em políticas de diferenciação e de segmentação, mas todas essas mudanças não fazem mais que ampliar a mercantilização dos modos de vida, alimentar um pouco mais o frenesi das necessidades e avançar um grau na lógica do "sempre mais, sempre novo" que no último século já concretizou como o sucesso que se conhece ${ }^{14}$.

Nota-se, portanto, que as inovações empresariais caminham nesse sentido, auxiliando a moldar uma sociedade na qual, é cobrado cada vez mais das pessoas, ter ou ao menos fazer aparentar ter, um determinado padrão - em que as pessoas devem possuir, como o próprio autor diz, "sempre mais" bens, "sempre novos", ainda que o anterior não seja obsoleto - para que assim, os sujeitos possam ser incluídos e aceitos em seu núcleo social, numa espécie de "consumo ostentação".

A partir disso, o valor dos bens materiais tem superado o valor humano, em um contexto em que se vende uma "felicidade artificial" - termo do médico Ronald W. Dworkin ${ }^{15}$, utilizado em sua obra a fim de criticar essa obrigação hodierna de ser

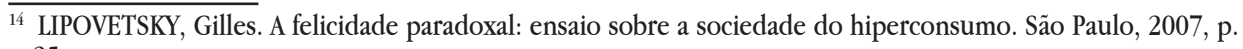
25.

${ }^{15}$ DWORKIN, Ronald. Felicidade artificial: o lado negro da nova classe feliz. São Paulo, 2007. 
feliz, situação reforçada pelas plataformas digitais, sobretudo, as redes sociais - a qual nos leva a expressão de Gilles Lipovetsky ${ }^{16}$, "felicidade paradoxal", a qual, seria exatamente essa busca constante pela felicidade, mas não uma felicidade real, de modo que em seu livro o autor critica principalmente a utilização de antidepressivos como forma de alcançar essa felicidade passageira e irreal, a qual se expressa em objetos, bens materiais e não em momentos ou em um estado mental, psíquico de bem-estar de fato.

Dessa forma, podemos entender as redes sociais, como uma nova forma de "felicidade", que na verdade, reforça padrões estéticos e propõe uma felicidade constante, inalcançável, induzindo os sujeitos ao consumismo, os quais, instigados a atingir essa máxima exigida em meio à sociedade, passam a ter atitudes irresponsáveis, principalmente referentes ao crédito, fator que agrava diretamente esse forte expoente das causas do superendividamento.

Nesse ínterim, induzido ao consumo do supérfluo e do sempre novo, e, portanto, em estado de vulnerabilidade, o consumidor verá as plataformas digitais acentuarem ainda mais o gravame da situação, uma vez que, proporcionam, como citado, uma facilitação à aquisição dos bens, levando muitas vezes a um consumo irrefletido. Isto é, se antes, o consumidor ao adentrar na loja, teria tempo para escolher, experimentar e entrar na fila para então pagar, ou seja, teria vários momentos para refletir sobre sua compra, agora, com um único clique, este mesmo consumidor realiza a compra influenciado por modelos de inteligência artificial que o levam a decidir por impulso

Além de a disponibilização do crédito desfazer a limitação que o dinheiro impresso trazia - findado o dinheiro, findavam as compras - com o crédito e as plataformas virtuais, deixa de haver uma limitação de espaço físico e de tempo para reflexão. Sobre isso, para Antônio Benjamin, Claudia Lima Marques e Leonardo Bessa

[...] O mundo virtual modificou os hábitos de consumo, mudou o tempo de consumo, agilizou as informações e expandiu as possibilidades de publicidade, agravando os conflitos de consumo e a própria vulnerabilidade informacional, técnica, fática e jurídica do consumidor. ${ }^{17}$

Nessa perspectiva, a citada vulnerabilidade do consumidor é acentuada, a

${ }^{17}$ BENJAMIN, Antônio Herman; MARQUES, Claudia Lima; BESSA, Leonardo Roscoe. Manual de direito do consumidor. São Paulo, 2014, p. 50. 
falta de informação, técnica, conhecimento sobre os próprios direitos, deixam os consumidores a mercê do jogo empresarial e publicitário das marcas. A transmutação do mercado para o mundo virtual deixou diversas situações não regularizadas, abrindo caminho para que as empresas se utilizassem da falta de fiscalização, de normas claras e da fata de conhecimento dos consumidores, para praticar condutas abusivas.

Atualmente, a publicidade, sobretudo, no âmbito virtual, em que a fluidez desse modelo de negócio impede a fiscalização adequada. A conectividade tornou-se tão forte, que passou a produzir formas alternativas para as transações eletrônicas, pois já há a possibilidade de substituição do cartão de crédito por pulseiras ou adesivos, e mais ainda, a substituição do dinheiro, por moedas inteiramente virtuais - a exemplo dos bitcoins - excluindo completamente o fator físico dos gastos, tornando-se cada vez mais fácil para o consumidor, gastar sem ao menos perceber. As empresas se utilizam das plataformas digitais e dessa falta de instrução do consumidor, não apenas relacionado aos direitos, como citado, mas sobre a própria técnica virtual, visto que muitas pessoas ainda não sabem utilizar todos os artifícios disponibilizados virtualmente, logo, demasiadas são as reclamações sobre serviços ruins, que não foram solicitados ou que se autorrenovam.

Desse modo, o excesso de confiança do consumidor no comércio eletrônico contrasta com um atendimento pós-venda vacilante. Se antes todas as reclamações eram voltadas para o telemarketing, em que ao menos havia um contato com um ser humano, hoje, as reclamações se direcionam a softwares de atendimento com inteligência artificial, algo muito mais vantajoso financeiramente para as empresas.

Houve uma profunda modificação no tempo do consumo, de modo que, não só se facilitou a aquisição de bens, mas também a realização de transações bancárias, por exemplo. A situação com as pulseiras e adesivos no lugar do cartão de crédito, já é real em agências brasileiras, de modo que o poder aquisitivo - na verdade, crédito fictício - pode acompanhar o consumidor em todos os lugares, havendo ainda, dentro dessas transações, em compras inferiores a 50 reais, a dispensabilidade de senha, ou seja, com o simples aproximar da "pulseira de crédito" à máquina, efetua-se a compra. Ademais, a maior parte das transações bancárias hodiernamente podem ser efetuadas por meio de aplicativos para celular, transferências, pagamentos e mais recentemente, propostas de transações bancárias através de redes sociais. Logo, exemplifica-se, a partir da redução do tempo de consumo e, por sua 
vez, facilidade em consumir, de modo que há como consequência a propiciação do consumidor ao superendividamento, igualmente facilitada e através de decisões irrefletidas, haja vista o novo tempo das transações comerciais.

\subsection{EFEITOS SOBRE OS INDIVÍDUOS E A SOCIEDADE}

O superendividamento acarreta uma série de consequências ao consumidor, atingindo em sentido privado, sua saúde e a qualidade de vida e, em caráter sistêmico, a coletividade e o mercado.

No que tange à preocupação com o consumidor individualmente considerado, a insolvência gera adversidades várias, sobretudo porque, vivendo em uma sociedade capitalista, torna-se impossível falar em qualidade de vida, sem equilíbrio financeiro. É nesse quadro que se pode discutir que o superendividamento compromete não apenas a projeção de felicidade artificial condicionada à satisfação dos desejos de consumo, mas a própria subsistência do consumidor e sua família, fomentando conflitos e constrangimento.

A partir dessa análise, é importante sublinhar a ideia de mínimo existencial, definida pela Comissão de Juristas incumbidos de atualizar o CDC como "quantia capaz de assegurar a vida digna do indivíduo e seu núcleo familiar destinada à manutenção das despesas de sobrevivência, tais como água, luz, alimentos, saúde, educação, transporte entre outras" ${ }^{\prime 1}$. Nessa perspectiva, o consumidor superendividado encontra-se desprovido do seu mínimo existencial, afetado em seu direito de possuir uma vida digna, já que não tem como arcar com necessidades básicas, ficando, portanto, à margem da sociedade de consumo, com repercussões que ultrapassam o âmbito financeiro, adentrando no aspecto psicológico e social da vida do consumidor, não surpreendendo, por sua vez, os problemas de saúde advindos da acumulação de dívidas, podendo levar a condições de ansiedade, depressão e até mesmo suicídio.

O Procon, a partir de um projeto-piloto, voltado para assistência de consumidores superendividados, identificou que dentre uma estimativa de 280 pessoas, há "forte sofrimento psíquico por causa do superendividamento" de modo que muitos "deixam de dormir, passam a ter problemas em casa, e até se divorciam" influenciados pela problemática - foi o que apontou Vera Remedi, assessora executiva do

${ }^{18}$ BERTONCELLO, Káren Rick Danilevicz. Superendividamento do consumidor: mínimo existencial: casos concretos. 2015, p. 70. 
Procon-SP, sobre a pesquisa efetuada ${ }^{19}$.

Tendo em vista, portanto, a gravidade e complexidade do problema do superendividamento, há que se falar a respeito do tratamento do fenômeno no Brasil, o qual, tal como citado, é diferente dos demais países que, deparados com esse crescente transtorno, procuraram elaborar um modelo para amenizar e/ou solucionar a questão, ainda não há no país, inexistindo uma definição mais delineada sobre a forma como tratar os consumidores superendividados e trazê-los de volta do limbo psicossocial e econômico, à sociedade de consumo, sobretudo mais conscientes acerca dos riscos do superendividamento.

Sobre isso, o mais próximo que há de um método que busca solucionar a problemática, são, o PL no 3515/2015, atualmente em tramitação na Câmara dos Deputados, e o projeto-piloto do Poder Judiciário do Rio Grande do Sul, os quais, de modo geral, buscam implantar uma política de conciliação entre os superendividados e seus credores ${ }^{20}$, além de que, no que tange o PL $n^{0} 3515 / 2015$ há a propositura da normatização do acesso ao crédito, no sentido de promover informações ao consumidor sobre os contratos de crédito, devendo esclarecer, aconselhar e advertir o mesmo sobre as condições da transação, além da proibição do assédio de consumo e da publicidade abusiva relativa ao crédito, incentivo ao crédito responsável e à educação financeira, propondo, ainda, incluir o tema nas grades escolares.

\section{O SUPERENDIVIDAMENTO DENTRO DO CONTEXTO DE DESIGUALDADE SOCIAL NO BRASIL}

A partir de tudo que foi explicitado tanto no âmbito da desigualdade de classes, quanto no que diz respeito a problemática de superendividamento no Brasil, far-se-á a relação entre os dois temas, no sentido de avaliar os efeitos que o fenômeno do superendividamento tem produzido no contexto da segregação de classes, além do impacto macro, no que tange o crescente agravo da disparidade socioeconômica no país.

\footnotetext{
${ }_{19}$ SOUSA, Dayanne; VASCONCELOS, Eduardo. Endividamento tem impacto na saúde, aponta Procon. Estadão, 2012.

${ }^{20}$ Desde a implementação do projeto, em 2006, já foram realizadas mais de 3 mil audiências de conciliação no intuito de harmonizar a situação entre devedores e credores, de modo que, a conciliação coletiva dos casos tem previsão na Consolidação Normativa Judicial do Rio Grande do Sul, Art 1.040-A. (RIO GRANDE DO SUL. Consolidação normativa judicial. Corregedoria Geral da Justiça do Porto Alegre, 2006).
} 


\subsection{SEGREGAÇÃO EM CLASSES SOCIAIS}

Sobre o tema em questão, como colocado por Amartya Sen em Desigualdade Reexaminada, os indivíduos pertencentes às classes mais baixas, e, portanto, a parcela mais pobre da sociedade, "enfrentariam as desigualdades sociais, ajustando os seus desejos às suas possibilidades" ${ }^{21}$, o que seria natural que ocorresse, já que não sendo possibilitado ao ente condições efetivas de melhoria socioeconômica tal como ocorre no Brasil - lhe caberia o conformismo. Todavia, com a facilitação do acesso ao crédito, a afirmação de Sen sofre uma modificação decisiva, no sentido em que, não mais se vê o consumidor impossibilitado de alcançar seus "desejos", isso porque suas possibilidades reais, que lhe serviriam de parâmetro e limitação, se expandiram com a disponibilização do crédito - limite artificial, muitas vezes utilizado de maneira irresponsável.

Entretanto, se por um lado é valorável a oportunidade de pessoas de diferentes classes conseguirem atingir necessidades de consumo de forma universal, por outro, a utilização do crédito de modo irresponsável gerará o superendividamento desse grupo muito mais dependente do crédito, agravando, paradoxalmente, sua posição social e econômica - sobretudo num modelo econômico predatório em que as necessidades de consumo, passam a ser forjadas artificialmente pela indústria cultural e influenciam as escolhas, muitas vezes sob a forma de assédio ao consumo.

A oferta facilitada do crédito e o assédio ao consumo geram a falta de controle financeiro, levando o consumidor a perder a racionalidade decisória sobre os limites de sua capacidade de pagamento, optando por decisões emocionais e irrefletidas, o que se agrava em grupos em estado de vulnerabilidade agravada, como ocorre com famílias de baixa renda e já excluídas socialmente, muito mais carentes e suscetíveis ao apelo midiático de alcançarem um novo status social através do consumo.

É inegável da existência de uma grave vulnerabilidade comportamental deste indivíduo que aposta na sua emancipação social e felicidade na aquisição de bens de consumo e terá no crédito fácil uma ferramenta importante na antecipação de suas vontades, até porque o tempo do consumo e as limitações materiais antes existentes - a partir do dinheiro e das lojas físicas - foram superadas. Da mesma

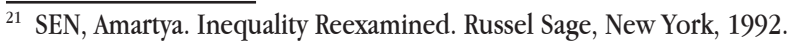


forma, os padrões estéticos e sociais estão em constante movimento, sendo cada vez mais difícil se aceitar como pessoa e sujeito social diante de uma identidade tão oscilante produzida pelo mercado de consumo.

Dialoga-se cada vez mais com as máquinas e sua afinada inteligência artificial em plataformas virtuais, reduzindo-se o tempo dispensado para as relações pessoais autênticas. O consumidor de hoje é egoísta, mas está solitário e superendividado. Esse indivíduo está envolto em um contexto de autoafirmação social e satisfação hedonista, o que se revela mais sensível em grupos de consumidores já marginalizados socialmente.

Percebe-se, portanto, a complexidade que existe entre a organização social brasileira, envolta em uma realidade extremamente desigual, e o aumento dos casos de superendividamento no país. Os consumidores no Brasil possuem além da vulnerabilidade econômica, uma carga de vulnerabilidade social e psicológica, relacionadas ao contexto - já explorado - em que se encontra o país. Nesse sentido, Amartya Sen afirma que

É também necessário ter em atenção a impossibilidade de responsabilizar as pessoas pelas suas escolhas individuais, especialmente aquelas que apresentam incapacidades físicas ou mentais, ou carências resultantes da destituição social uma vez que tal responsabilização pressuporia a completa disponibilidade e acessibilidade universal de conhecimento e habilidade das pessoas em reconhecer e escolher alternativas, o que não acontece em nenhuma sociedade. ${ }^{22}$

Assim, a responsabilização do indivíduo superendividado como único culpado pela contratação do crédito se revela inadequada e busca isentar o fornecedor do crédito que atua na infralegalidade quando assedia esse consumidor, muitas vezes já endividado.

\subsection{A TUTELA JURÍDICA DOS DANOS AO CONSUMIDOR}

A proteção do consumidor se dá a partir do reconhecimento de seus direitos humanos, inseparáveis da promoção de sua dignidade, inerente a toda pessoa humana - independente de classe econômica, mas também, positivada na Consti-

\footnotetext{
${ }^{22}$ SEN, Amartya. Inequality Reexamined. Russel Sage, New York, 1992.
} 
tuição Federal (Art. $1^{\circ}$, III, CF), e no Código do Consumidor (art. $4^{\circ}$, caput), em que se estabelece dentro de um rol de princípios a necessidade de respeito à dignidade do consumidor, além de saúde, segurança, proteção dos interesses econômicos, melhoria da qualidade de vida, além da necessidade de transparência nas relações de consumo. Cabendo, desse modo, visualizar a proteção do mínimo existencial e da saúde física e mental dos indivíduos, afastando a tese da falta de educação financeira com única causa do superendividamento, devendo-se olhar de maneira ampla para a problemática, de forma a enxergá-la do ponto de vista social, isto é, a luz de uma definição de consumidor, enquanto categoria.

A partir da compreensão do superendividamento dentro de uma perspectiva de grupo, aumentam-se as possibilidades de solução, levando-se em consideração os muitos espaços políticos de deliberação criados pela lei $\mathrm{n}^{\circ}$ 8.078/90 (CDC), tais como o controle coletivo da oferta de crédito com a imposição de sanções específicas para o fornecedor de crédito, modulação da liberdade publicitária, com vistas a combater o assédio de consumo, propositura de ações coletivas, nos termos do artigo 83 do CDC, ou mesmo a celebração de acordos e convenções coletivas de consumo, com base no artigo 107 do CDC.

Uma vez que, a partir da ideia de que o consumidor não está sozinho e que seu problema é coletivo, serão fortalecidos os laços de empatia social, gerando uma força contra majoritária em relação ao poder econômico do fornecedor, criando melhores condições para a correção de práticas abusivas e a imposição de novas obrigações e deveres éticos.

Urge proteger o consumidor do assédio ao consumo irresponsável, atrelado à massificação midiática e a indústria cultural - reiterada mais à frente - que minguam a autonomia dos indivíduos à uma ilusão de escolhas na verdade pré-definidas e desprovidas de identidade, oriundas de uma padronização dos entes aos moldes socioculturais e midiáticos. Sobre isso, Loiane Verbicaro e Dennis Soares afirmam

A padronização proporcionada pelo modo de produção das sociedades industriais gerou o indivíduo ilusório, a pseudoindividualidade ou o caráter fictício da subjetividade assumidos na era do liberalismo burguês com sua concepção de indivíduo como ser genérico, reforçada por um sistema político e jurídico amparados em um complexo de normas de estrutura geral, impessoal e abstrata ${ }^{23}[\ldots]$.

${ }^{23}$ VERBICARO, Loiane; SOARES, Dennis. A indústria cultural e o caráter fictício da individualidade na definição de consumidor-sociedade global. Revista Jurídica Cesumar, n. 1, p. 107-131, jan/abr. 2017, p. 114. 
Nesse contexto, haverá, além do dano existencial do consumidor (comprometimento de seu projeto de vida), em razão das mazelas psicossociais advindas da problemática - como a exclusão social, sensação impotência sobre a situação e depressão, perda do poder aquisitivo da massa trabalhadora, desemprego, desestruturação familiar pela diminuição do padrão de consumo (separação e divórcio), fatores esses agravantes da desigualdade social no país.

De modo que, é dever do Estado, visando atender o princípio da dignidade da pessoa humana, implementar uma política de prevenção ao superendividamento - implementando normas e políticas públicas, que regularizem e fiscalizem a oferta do crédito pelas instituições financeiras, bem como voltadas para a promoção da educação financeira do consumidor, deveres respectivamente previstos no CDC em seu artigo $4^{\circ}$, incisos II e IV.

Fundamental é o acesso à informação qualificada na tomada do crédito, justamente para garantir plena liberdade de escolha do consumidor

O fornecedor menospreza a importância do consumidor ao omitir informações essenciais ao consumidor, premeditando influenciar negativamente a liberdade de escolha pela supressão de dados que possam influir negativamente na opção do consumidor, aumentando, sobremaneira, a conflituosidade social $^{24}$.

Exige-se, portanto, uma atitude mais proativa dos fornecedores - condutas responsáveis, não abusivas e desvinculadas de assédio para contratação do crédito, assim como do Estado, no sentido de implementar maior controle abstrato na oferta do crédito e da malsinada democratização das dívidas, sancionando os fornecedores de maneira efetiva e transindividual.

Portanto, a exigência de condutas preventivas ao superendividamento não recai apenas sobre o segmento financeiro, mas, de modo geral, a todos os fornecedores em suas transações de consumo, criando-se um ambiente de transparência e respeito recíproco com os consumidores.

\footnotetext{
${ }^{24}$ VERBICARO, Dennis; SILVA, João Vitor; LEAL, Pastora. O mito do dano moral e a banalização da proteção jurídica do consumidor pelo judiciário brasileiro. Revista de Direito do Consumidor, São Paulo, ano 26, p. 75-99. nov./dez. 2017, p. 84.
} 


\subsection{A INFLUÊNCIA DO MEIO SOBRE O CONSUMO}

A massificação do acesso ao crédito e o assédio de consumo estão diretamente relacionados ao fenômeno do superendividamento. Um forte exemplo ocorre com a aquisição de automóveis - o Brasil foi considerado, em 2014, o quarto maior consumidor de automóveis do mundo, caindo nesse ranking em $2016^{25}$, haja vista a crise econômica daquele ano, porém voltando a subir agora em 2018- isso porque o assédio e a oferta de crédito para aquisição de automóveis ilustram bem políticas econômicas de estímulo ao consumo interno, com repercussões diretas no endividamento das famílias brasileiras. Ter um carro novo é "vendido" pela publicidade como símbolo de ascensão social e autorreconhecimento do grupo, tendo influência cultural mais decisiva que a aquisição da casa própria no Brasil.

Desse modo, a parcela da sociedade brasileira, pertencente à classe $\mathrm{C}$, almeja enquanto uma de suas prioridades a aquisição de um automóvel; a classe B, em sua maioria, acredita na necessidade indispensável de possuir ao menos um automóvel; e na classe A ocorre uma disputa - relacionada à necessidade de firmar-se socialmente - entre quem possui o mais recente, mais bonito ou mais oneroso. Com isso, em escalas diferentes, as três realidades citadas são prejudicadas pelo assédio de consumo e é por isso que a realidade de superendividamento pode e está atingindo cidadãos dos mais variados padrões econômicos.

É notável, através do exemplo, o contexto de assédio e de vulnerabilidade do consumidor brasileiro, de modo que o mesmo acredita na necessidade indisponível do automóvel, por razões, principalmente de influência social e midiática e, portanto, na ilusão de que deve obtê-lo de qualquer forma, situação, a qual, leva os indivíduos a incorrer em erros relacionados a suas finanças, cair na fantasia do crédito facilitado e endividar-se.

Sobre isso, Pierre Bourdieu, compreende que o indivíduo é visto na sociedade a partir de seus atos, que determinam o seu "habitus", definido pelo mesmo como "sistema de disposições socialmente constituídas que, enquanto estruturas estruturadas e estruturantes, constituem o princípio gerador e unificador do conjunto das práticas e das ideologias características de um grupo de agentes"26.

Sendo esse termo relacionado ao status social, de modo que os atos praticados pelo sujeito, na realidade, não pertencem a ele, e sim ao ideal coletivo que o

${ }^{26}$ BOURDIEU, Pierre. A Economia das Trocas Simbólicas. São Paulo, 2007, p. 191. 
impulsiona a agir no sentido do que acredita ou considera correto, moral, necessário - fatores que deverão ser seguidos para que o indivíduo se encaixe ao meio onde vive. Essa afirmação configura um ideal de "falsa" autonomia, posto que as escolhas pessoais são fortemente influenciadas pelos entendimentos e pré-conceitos coletivos, de modo que o acesso irresponsável ao crédito irá prejudicar, ainda mais, essa autonomia já relativizada.

Sobre esse contexto, afirma Dennis Verbicaro que "[...] o indivíduo se tornou refém de seus impulsos materialistas que, sobrevalorizados pelos meios de publicidade e convencimento em massa, são vendidos como verdadeiras necessidades de consumo" ${ }^{27}$.

O assédio ao consumo, e de forma mais gravosa, o consumismo afeta os indivíduos, direcionando-os a práticas que, desassociadas de informação qualificada, educação financeira e da proteção/prevenção estatal, têm sua frequência acentuada, aumentando os casos de superendividados no Brasil.

\subsection{CONTROLE PRÉ-CONTRATUAL E O PRINCÍPIO DA TRANSPARÊNCIA}

O princípio da transparência, uma das bases fundantes do núcleo axiológico do Código do Consumidor brasileiro, deve estar presente na fase de formação do vínculo contratual, de modo que o consumidor precisa estar consciente dos riscos da contratação, e desse modo, devidamente informado acerca do alcance e eventual onerosidade daquela transação, até mesmo porque reconhecida sua vulnerabilidade informacional.

Nesse sentido, ao adentrar no contexto de desigualdade social brasileira, e, portanto, tendo em vista os fatores de baixa qualidade de ensino do país, o dever informacional ganha destaque, pois sua omissão tem maior potencial de causar danos aos consumidores integrantes de classes sociais mais baixas.

No que tange, mais especificamente à fase pré-contratual do crédito, os cuidados devem ser ainda maiores, uma vez que deve exigir dos fornecedores uma explicação detalhada e prática sobre a disponibilização, os juros que incorrerão sobre possíveis empréstimos, e como a contratação afetará a renda do contratante, quais os riscos da cumulação de juros, e a importância da utilização consciente do crédito. Sobre o perigo da má-informação tem-se que

\footnotetext{
${ }^{27}$ VERBICARO, Dennis. A política nacional das relações de consumo como modelo de democracia deliberativa. Revista Jurídica da Presidência, n. 119, out/jan. 2018, p. 537.
} 
Com efeito, as informações obscuras e incompletas moldam a racionalidade do consumidor, levando-o a tomar decisões potencialmente arriscadas [...] Portanto, além do crédito a ser concedido em má-qualidade, a assimetria informacional figura como sendo o segundo ponto de tensão na relação entre consumidor e fornecedor ${ }^{28}$.

Portanto, é necessária tutela a fim de modificar uma realidade em que, o consumidor encontra-se em um contexto de vulnerabilidade referente à informação e que, sem o peso da regulamentação e fiscalização adequadas, os fornecedores a despeito do cumprimento dos princípios da transparência e da boa-fé, aproveitam-se da situação, de modo que, tal como cita Eduardo Dallagnol Lemos ${ }^{29}$

É valoroso destacar a publicidade agressiva muitas vezes utilizada pelos provedores de crédito, que, já na fase pré-contratual, acabam violando a manifestação de vontade do consumidor - anunciando, por exemplo, a contratação de crédito "rápido e fácil", "crédito sem consulta para negativado" ou, ainda, "crédito ideal para aposentados e pensionistas do INSS. ${ }^{30}$ Essa forma de publicidade ${ }^{31}$, por óbvio, estimula a obtenção do crédito - adquirido, possivelmente, de maneira irrefletida e irracional -, e é uma das principais causas para o endividamento excessivo atingindo, principalmente, os segmentos mais vulneráveis da população.

E, portanto, utilizam-se de artifícios abusivos para influenciar o consumidor ao consumo irresponsável do crédito, reiterando-se a necessidade de controle dessa fase pré-contratual, haja vista ser porta de entrada para um abismo financeiro e, por sua vez, para o superendividamento.

Nessa perspectiva, a oferta de informação qualificada - adequada à realidade brasileira - prevista no art. $6^{\circ}$ III do CDC, além de ser direito básico do con-

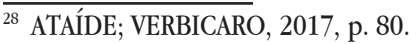

${ }^{29}$ LEMOS, Eduardo. Alternativas ao superendividamento do consumidor brasileiro. Porto Alegre, 2015. p. 27.

${ }^{30}$ LIMA, Clarissa Costa de. Empréstimo responsável: os deveres de informação nos contratos de crédito e a proteção do consumidor contra o superendividamento. In: BERTONCELLO; Káren Rick Danilevicz (org.). Superendividamento aplicado: aspectos doutrinários e experiência no poder judiciário. Rio de Janeiro, RJ: GZ, 2010. p. 42.

${ }^{31}$ COSTA, Geraldo de Faria Martins da. Superendividamento: solidariedade e boa-fé. In: MARQUES, Claudia Lima; CAVALLAZZI, Rosângela Lunardelli (coord.). Direitos do consumidor endividado: superendividamento e crédito. São Paulo: Revista dos Tribunais, 2006. p. 249.
} 
sumidor, é fundamental para minimizar os riscos da aquisição do crédito, devendo ser fiscalizada de forma permanente e efetiva pelo Estado.

Não se olvide que o discernimento sobre os riscos das transações financeiras e bancárias, por exemplo, previne o consumidor de arriscar sua renda e seu mínimo existencial. Ademais, além da orientação sobre essas situações mais específicas, o preparo no que tange a importância da organização mensal da relação renda/gastos ajuda os indivíduos a compreenderem suas finanças e seu real poder aquisitivo, de modo que consigam sopesar suas prioridades, minimizando a influência negativa do assédio de consumo, da indústria cultural, da obsolescência planejada etc.

\subsection{A INFLUÊNCIA DA INDÚSTRIA CULTURAL}

Sobre isso, o assédio advindo da indústria cultural - termo que define a forma de produção de cultura e arte em escala industrial, a partir do sistema capitalista - afeta a sociedade no sentido de manipular a coletividade em um padrão que extrai dos entes a sua individualidade e poder real de escolha, havendo a relativização da autonomia e atrelando a aquisição de bens à uma necessidade para inclusão social e alcance de um estado de felicidade - vendido por meio dos veículos midiáticos, enquanto patamar a ser atingido para efetividade da realização pessoal.

Nesse viés, a indústria cultural viabiliza a manutenção dos valores capitalistas pelos mecanismos de uniformização dos desejos, os quais são impostos aos entes como essenciais para sua própria existência social.

[...] Ao seguir os modelos erráticos de conduta impingidos pelo mercado, alcançará uma pseudo felicidade, pois da euforia do sentimento breve de autossatisfação ou pertencimento social, enfrentará a frustação e a angústia de um novo projeto de consumo ${ }^{32}$.

Situação exemplificada por meio do que ocorre com a indústria de automóveis no Brasil, em que mais do que a preocupação ou necessidade de um serviço melhor de mobilidade pública, há a observância do fator "status" que esse bem acarreta, e isso não no sentido em que a sociedade é efetivamente fútil e dotada de

\footnotetext{
32 VERBICARO, Dennis; ALCÂNTARA, Ana Beatriz. A Percepção do Sexismo face à Cultura do Consumo e a Hipervulnerabilidade da Mulher no Âmbito do Assédio Discriminatório de Gênero. Revista Pensamento Jurídico, São Paulo, n. 1, jan/jun. 2017, p. 178.
} 
desejos superficiais, mas porque são esses os valores impostos a ela pelos apelos propagandísticos, os quais despertam a vontade de aquisição de determinados bens e reafirmam sua necessidade, a qual é na verdade, irreal.

Nesse sentido, a partir da formação ilusória de necessidades de consumo produzidas pela indústria cultural, haja vista imposição de valores e modelos de vida padronizados, haverá inevitável prejuízo à autonomia dos indivíduos. Há a coisificação do homem, mero subordinado e obediente aos hábitos coletivamente comuns, que a partir da definição das formas de agir, do que adquirir e como se expressar para efetiva existência em meio a sociedade de consumo ${ }^{33}$ alimenta um capitalismo predatório e agrava a desproporção na divisão de renda.

Consoante a esse aspecto de massificação das vontades e da felicidade dos indivíduos, Ronald W. Dworkin expressa que "Adaptaram a Felicidade Artificial aos princípios de produção em massa, tornando-a viável para milhões de pessoas pelo menor custo possível" ${ }^{4}$, de modo que passa-se a vender "felicidade", seja traduzida em produtos como vestuário e automóveis, seja em casos mais sérios, e principal foco de crítica do autor citado, por meio de medicamentos, sobre isso, Dworkin ainda afirma

O crescimento das seguradoras de saúde ajudou o movimento de Felicidade Artificial tanto na esfera dos interesses quanto na da ideologia. Na esfera dos interesses, os executivos das operadoras de saúde reorganizaram a assistência médica para conceder mais poder aos médicos de atenção primária às expensas dos psiquiatras, garantindo a nova e agressiva política a favor das drogas psicotrópicas. No âmbito da ideologia, os executivos das operadoras de saúde deram suporte à nova visão de mundo dos médicos revolucionários: entre os médicos de medicina alternativa, a crença no impacto da mente sobre a saúde; e entre os médicos de exercícios, a crença na medicina preventiva ${ }^{35}$.

Notando-se, por conseguinte que há uma banalização do bem-estar real dos indivíduos, a partir do momento em que se dá um valor para a felicidade e a objetifica, tabelando-a em preços, produtos e medicamentos. Desse modo, fica clara a des-

\footnotetext{
33 Tema aprofundado no texto: A indústria cultural e o caráter fictício da individualidade na definição de consumidor-comunidade global. (VERBICARO, Loiane; SOARES, Dennis, 2017, p. 108-130)

${ }^{34}$ DWORKIN, Ronald W. Felicidade artificial: o lado negro da nova classe feliz. São Paulo, 2007, p 126.

35 DWORKIN, 2007, p. 126-127.
} 
personalização dos entes às determinações do sistema capitalista e à mercantilização dos padrões sociais, as quais, contribuem para ocultar em um discurso de igualdade e liberdade - fictícias - as desigualdades sociais presentes no país. O controle da indústria cultural juntamente ao sistema socioeconômico e político brasileiro exercido sobre os entes, monopoliza as determinações socioculturais em favor do sistema - lucratividade e produção - e da indústria, situação aproveitada pelos fornecedores para promover a si ao consumismo irresponsável, em uma imitação de padrões estéticos e de vida.

A indústria cultural inclina os indivíduos a fazer o possível para atingir um padrão estético-comportamental, construído e reforçado pelos fornecedores. Situação que demonstra a necessidade de resgate da individualidade do consumidor, enquanto ser humano dotado de vontade própria e, portanto, autonomia sobre suas escolhas.

Impõem-se, portanto, medidas como a proibição e controle da publicidade, ampliação das redes de comunicação entre consumidores, fortalecimento das plataformas de compartilhamento de experiências, como espelho real do comportamento dos fornecedores, tudo de modo a reforçar maior empoderamento social do consumidor no mercado, o que impactará positivamente na mudança de comportamento empresarial.

\subsection{AVALIAÇÃO COMPORTAMENTAL DOS CONSUMIDORES A PARTIR DO CONTEX- TO DE CLASSES}

Há que se fazer a avaliação comportamental de cada uma das mesmas a fim de se avaliar o impacto do assédio de consumo no âmbito específico de cada classe social.

Aparentemente, se poderia dizer que a classe A estaria mais "protegida" do fenômeno do superendividamento, todavia, a vulnerabilidade também lhes acena, haja vista o contexto psicológico e social onde estão inseridos, pois além da forte pressão midiática sobre o padrão de beleza, status social, e o consumo de bens de luxo para ostentação igualmente atingem sua capacidade financeira, pois os efeitos de uma competição "velada" por um protagonismo social estimulam comportamentos erráticos e financeiramente perigosos.

A classe média, por sua vez, encontra-se em um intermédio entre duas realidades opostas, a riqueza e a pobreza, de tal forma que a vontade de se distanciar da 
pobreza a faz ceder aos apelos do assédio de consumo, que vende um caminho mais rápido para a almejada ascensão social, desde que o consumidor esteja disposto a utilizar os bens de consumo como instrumentos de realização pessoal e profissional, a partir do aumento artificial de sua renda pelo uso abusivo do crédito.

Utilizando-se do exemplo do automóvel, podemos compreender que, um indivíduo, pertencente a classe $\mathrm{C}$, que por muito tempo não teve um carro, e, portanto, conseguiu viver sem o automóvel, saberá contornar a situação, tendo uma facilidade maior para dispor dele. Todavia, um cidadão da classe B poderá entender enquanto um grande sacrifício a disponibilidade do seu automóvel. Clarissa Lima expõe que

O sacrifício pode não ser novidade para devedores com renda baixa, mais habituados a driblar o orçamento para conseguir atender as necessidades de subsistência da família, mas para devedores de classe média priorizar o pagamento das dívidas acordadas pode significar uma grande mudança na sua rotina e no seu estilo de vida ${ }^{36}$.

Notando-se, dessa forma, que a problemática se torna ainda maior, quando, enquadrada nesse contexto de classes, envolve o âmbito psíquico.

Nessa perspectiva, deparamo-nos, finalmente, com a análise da classe $C$, que apesar de ser a mais "acostumada" com uma condição socioeconômica inferior às demais, sem vastidão de bens e/ou regalias, é também a mais exposta no que tange às deficiências da informação na tomada do crédito. Esses consumidores, em sua maioria, têm um nível de escolaridade baixo, de modo que uma pequena extravagância no consumo poderá ter um pacto imediato e duradouro no orçamento familiar, sem falar do assédio publicitário que os incita a experimentar novas sensações e a quebrar barreiras pelo consumo. Esse consumidor de baixa renda seria portador, portanto, de uma vulnerabilidade agravada, ou seja, de uma "hipervulnerabilidade", sobretudo em relação aos desejos antes limitados e agora possibilitados pelo crédito, e a falta de instrução quanto às relações de consumo e suas particularidades.

O consumidor hipervulnerável está reconhecido no art. 39, IV do CDC - a exemplo do que ocorre com o público infantil e idoso, que tem sua vulnerabilidade majorada por sua condição inerente de falta de consciência e instrução e/ou debilidade físico-psicológica.

${ }^{36}$ LIMA, Clarissa. O Tratamento do Superendividamento e o Direito de Recomeçar dos Consumidores. São Paulo, 2014, p. 142. 
Portanto, percebe-se que o superendividamento está presente em todas as classes sociais, muito embora com repercussões diferentes em cada segmento, mas agravando, em qualquer caso, a vulnerabilidade das classes mais baixas e, por conseguinte, a própria desigualdade social no Brasil. Um consumidor superendividado da classe $C$ seria considerado hipervulnerável em razão de uma dupla marginalização, seja socialmente em relação às condições mínimas de dignidade (acesso à saúde e educação), seja também em relação ao consumo (exclusão econômica).

Vê-se, portanto, a necessidade de mudança no sentido de proteger e educar o consumidor brasileiro. Proteção no que diz respeito ao assédio de consumo, que se expressa através de diversos meios, não apenas midiáticos, com a publicidade abusiva ou enganosas, mas também, com a facilitação do acesso ao crédito - segundo dados do Banco Central, nos últimos oito anos a quantidade de clientes bancários subiu em aproximadamente $45 \%$ e o número de contas correntes em $60 \%{ }^{37}$.

De modo a utilizar-se das ferramentas já presentes no Código do Consumidor, mas também, de modo abranger situações não tuteladas, esquecidas ou relativizadas, a exemplo do empréstimo para negativado, permitido no país, ainda que o próprio nome desta modalidade de disponibilização de crédito demonstre o seu risco, haja vista o contexto financeiro em que o consumidor já se encontra - negativado - e, portanto, já com dificuldades de lidar com seu orçamento.

Será preciso avançar no âmbito da vulnerabilidade comportamental do consumidor, sobretudo, para reconhecer que a desigualdade socioeconômica do Brasil favoreceu o surgimento de uma nova categoria de consumidor hipervulnerável: o consumidor de baixa renda e superendividado.

Além disso, medidas como as que estão previstas pelo PL no 3515/2015 são de extrema importância para a correção destas distorções, pois têm como objetivo a adequada prevenção do superendividamento, através de um controle normativo mais rigoroso da oferta do crédito, além de estimular a negociação entre os superendividados e seus credores.

Desse modo, somando os dispositivos já existentes no CDC à educação financeira, ao tratamento do consumidor enquanto o lado mais vulnerável da relação de consumo - de maneira a proteger seus interesses e necessidades - a maior participação dos consumidores em meio ao âmbito político, a fim de que em um caráter de responsabilidade tripartido - consumidor, fornecedor e Estado - e do

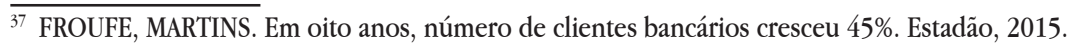


polo vulnerável em que se enquadra o consumidor, enquanto grupo, possa esse ter voz prática sobre seus direitos e necessidades, além da verificação das circunstâncias específicas dos casos concretos, a fim de proibir situações que induzam o consumidor ao erro ou o coloquem em uma posição de comprometimento do que lhe é de fato básico para viver, e por sua vez, afastando dessas relações o assédio ao consumo - seja esse escrachado ou velado, referente ao produto ou ao crédito - poderemos começar a caminhar no sentido de reduzir a incidência do superendividamento no Brasil, e com isso, o impacto que esse tem sobre a realidade social e econômica do país.

\section{CONCLUSÃO}

O texto buscou, a partir da análise do fenômeno do superendividamento e do contexto de desigualdade social e econômica do Brasil, enfrentar a problemática, isto é, entender as causas particulares de cada um desses temas, no intuito de relacioná-los, para procurar entender como essas realidades se influenciam, caracterizando um problema multidisciplinar e ainda mais complexo do que um mero diagnóstico econômico de situações individuais pulverizadas.

Defendeu-se que o superendividamento, conquanto esteja presente em todas as classes sociais e com efeitos nocivos diferentes nos projetos existenciais dos consumidores, agrava a desigualdade social e desencadeou o surgimento de uma nova categoria hipervulnerável: o consumidor de baixa renda superendividado.

Tem-se, portanto, no que diz respeito à desigualdade social, que a mesma tem suas causas e agravantes próprios, sendo o superendividamento um fenômeno que favorece o maior distanciamento entre as classes, embora o assédio de consumo e a oferta irresponsável do crédito insistam em sugerir o contrário, modulando o comportamento do consumidor a fazer do consumo um "refugio" para suas carências sociais e psicológicas.

Dessa forma, foi possível concluir que não apenas o superendividamento agrava a segregação de classes, mas essa realidade desigual influencia o próprio comportamento dos consumidores, contribuindo para a ocorrência do fenômeno no país.

Nesse sentido, além da análise dos pontos concretos, também, objetivou-se compreender os aspetos subjetivos dessa relação (superendividamento/desigualda- 
de), levando em conta questões psicossociais que interferem na expressão de um e outro tema, e se tornam ainda mais presentes na confluência destes - em virtude da influência do mercado na sociedade, a partir da indústria cultural e da vulnerabilidade comportamental do consumidor agravada pelo assédio de consumo.

De modo que esta realidade é acentuada pelo superendividamento, o qual tem como principais causas a oferta irresponsável do crédito, falta de informação qualificada e de educação financeira, afastando como proposto a ideia de que o problema do superendividado é de sua exclusiva responsabilidade, quando a temática deve ser tratada a fim de proteger a sociedade consumerista em sentido amplo, não mais enxergando apenas uma realidade de consumidor indivíduo, mas enquanto coletividade, haja vista condição - consumidor - inerente a própria existência nos dias atuais, abarcando inclusive a dignidade das pessoas humanas.

Nesse interim, vê-se a necessidade de aprovação do Projeto de Lei $\mathrm{n}^{\mathrm{o}}$ $3515 / 2015$, que busca melhor normatizar a distribuição/acesso ao crédito, mas também a promoção de medidas outras que promovam a redução do superendividamento, como o amparo do consumidor frente à publicidade abusiva, acesso à informação qualificada acerca dos riscos das transações financeiras e bancárias, controle da fase pré-contratual, a observância dos princípios da transparência, boa-fé, prevenção e da dignidade da pessoa humana, visando o tratamento especial do consumidor de baixa renda, haja vista sua hipervulnerabilidade, tudo em coerência com a Política Nacional das Relações de Consumo, sobretudo em relação à necessidade de educação financeira e maior envolvimento do consumidor nos espaços políticos de deliberação.

Desta forma, espera-se começar a caminhar no sentido de reduzir a incidência do superendividamento no Brasil, e com isso, o impacto que esse tem sobre a realidade social e econômica do país, além da manutenção e, portanto, minimização da influência da própria realidade sobre o fenômeno e seus cidadãos, de modo a progredir no sentido da proteção do consumidor brasileiro. 


\section{REFERÊNCIAS}

ATAÍDE, Camille; SOARES, Dennis. O crédito como objeto de tensão qualificada na relação de consumo e a necessidade de prevenção ao superendividamento. Revista da Faculdade de Direito da UFRGS, Porto Alegre, v. esp., n. 36, p. 73-89, out. 2017. BERTONCELLO, Káren Rick Danilevicz (org.). Superendividamento aplicado: aspectos doutrinários e experiência no poder judiciário. Rio de Janeiro, RJ: GZ, 2010.

BERTONCELLO, Káren Rick Danilevicz. Superendividamento do consumidor: mínimo existencial: casos concretos. São Paulo: Revista dos Tribunais, 2015.

BENJAMIN, Antônio Herman; MARQUES, Claudia Lima; BESSA, Leonardo Roscoe. Manual de direito do consumidor. 6. ed. São Paulo: RT, 2014.

BORGES, Rodolfo. O Brasil tem maior concentração de renda do mundo entre o 1\% mais rico. Disponível em: https:/brasil.elpais.com/brasil/2017/12/13/internacional/1513193348_895757.html. Acesso em: 12 fev. 2018.

BOURDIEU, Pierre. A Economia das Trocas Simbólicas. São Paulo: Perspectiva, 2007.

BRASIL. Câmara dos Deputados. Projeto de Lei PL $\mathbf{n}^{\mathbf{0}}$ 3515/15. Altera a Lei $\mathrm{n}^{\mathrm{o}}$ 8.078, de 11 de setembro de 1990 (CDC), e o art. 96 da Lei $\mathrm{n}^{0} 10.741$, de $1^{\circ}$ de outubro de 2003 (Estatuto do Idoso), para aperfeiçoar a disciplina do crédito ao consumidor e dispor sobre a prevenção e o tratamento do superendividamento. Disponível em: https://www.camara.leg.br/proposicoesWeb/fichadetramitacao?idProposicao $=2052490$ Acesso em: 11 fev. 2018 .

BRASIL. Código Civil. Lei $\mathrm{n}^{\mathrm{o}}$ 10.406, de 10 de janeiro de 2002. São Paulo: Revista dos Tribunais, 2002. BRASIL. Código do Consumidor. Lei $\mathrm{n}^{0}$ 8.078, de 11 de setembro de 1990. Disponível em: http://www.planalto.gov.br/ccivil_03/leis/18078.htm. Acesso em: $11 \mathrm{fev}$. 2018.

BRASIL. Constituição da República Federativa do Brasil, de 5 de outubro de 1988. Disponível em: http://www.planalto.gov.br/ccivil_03/Constituicao/Constituicao.htm. Acesso em: 12 fev. 2018. 
CORREA, Marcelo. Brasil é o $10^{\circ}$ país mais desigual do mundo. Disponível em: https://oglobo.globo.com/economia/brasil-o-10-pais-mais-desigual-do-mundo-21094828. Acesso em: 05 fev. 2018.

DWORKIN, Ronald W. Felicidade artificial: o lado negro da nova classe feliz. São Paulo: Planeta do Brasil, 2007.

FRANÇA. Code de la Consommation. Disponível em: https://www.legifrance.gouv. fr. Acesso em: 05 jan. 2018.

FROUFE, MARTINS. Em oito anos, número de clientes bancários cresceu 45\%. Disponível em: http://economia.estadao.com.br/noticias/geral,nos-ultimos-8-anos--houve-aumento-do-numero-de-clientes-de-quase-45-no-sfn-,1790869. Acesso em: $12 / 01 / 2018$.

LEITE, JOEL. China e EUA compram quatro de cada dez carros feitos no mundo. Disponível em: https://omundoemmovimento.blogosfera.uol.com.br/2016/03/02/ china-e-eua-compram-quatro-de-cada-dez-carros-feitos-no-mundo/. Acesso em: 13 jan. 2018.

LEMOS, Eduardo. Alternativas ao superendividamento do consumidor brasileiro. Disponível em: http://www.conteudojuridico.com.br/pdf/cj054980.pdf. Acesso em: 02 jan. 2018.

LIMA, Clarissa. O Tratamento do Superendividamento e o Direito de Recomeçar dos Consumidores. São Paulo: Revista dos Tribunais, 2014.

LIPOVETSKY, Gilles. A felicidade paradoxal: ensaio sobre a sociedade do hiperconsumo. São Paulo: Companhia das letras, 2007.

LOPES, José Reinaldo de Lima Lopes. Crédito ao consumidor e superendividamento: uma problemática geral. Revista de informação legislativa, v. 33, n. 129, jan./ mar. 1996.

MARQUES, Claudia Lima; CAVALAZZI, Rosângela Lunardelli. Direitos do consumidor endividado: Superendividamento e crédito. São Paulo; RT, 2006.

MARX, Karl. O capital. 7. ed. Rio de Janeiro: LTC, 1982. 
ORTIZ, Renato (org.). Pierre Bourdieu: sociologia. São Paulo: Ática, 1983. (Coleção Grandes Cientistas Sociais, vol. 39).

OLIVEIRA, Andressa. Crédito, inadimplência e os desafios para a proteção dos consumidores nos contratos bancários. Revista de Direito do Consumidor, ano 24. nov/dez. 2015.

PIKETTY, O capital no século XXI. Rio de Janeiro: Intrínseca, 2014.

PORDATA. Base de dados Portugal Contemporâneo: Fundação Francisco Manuel dos Santos. Disponível em: https:/www.pordata.pt/Europa/Índice+de+Gini+ (percentagem)-1541. Acesso em: 02 fev. 2017.

RIO GRANDE DO SUL. Consolidação normativa judicial. Corregedoria-Geral da Justiça do Porto Alegre, 2006. Disponível em: https://www.tjrs.jus.br/export/legislacao/estadual/doc/CNJCGJ_Provimento_008-2016.pdf. Acesso em: 03 fev. 2018.

SEN, Amartya. Inequality reexamined. Russel Sage, New York, 1992.

SOUSA, Dayanne; VASCONCELOS, Eduardo. Endividamento tem impacto na saúde, aponta Procon. Disponível em: http://economia.estadao.com.br/noticias/ geral,endividamento-tem-impacto-na-saude-aponta-procon,123185e. Acesso em: 10 fev. 2018.

VERBICARO, Dennis; ALCÂNTARA, Ana Beatriz. A Percepção do Sexismo face à cultura do consumo e a hipervulnerabilidade da mulher no âmbito do assédio discriminatório de gênero. Revista Pensamento Jurídico, São Paulo, n. 1, jan/jun. 2017.

VERBICARO, Dennis; SILVA, João Vitor; LEAL, Pastora. O mito do dano moral e a banalização da proteção jurídica do consumidor pelo judiciário brasileiro. Revista de Direito do Consumidor, São Paulo, ano 26, p. 75-99, nov-dez. 2017.

VERBICARO, Loiane; SOARES, Dennis. A indústria cultural e o caráter fictício da individualidade na definição de consumidor-sociedade global. Revista Jurídica Cesumar, n. 1, p. 107-131, jan/abr. 2017.

VERBICARO, Dennis. A política nacional das relações de consumo como modelo de democracia deliberativa. Revista Jurídica da Presidência, n. 119. out/jan. 2018. 
Recebido em: 30/10/2018

Aceito em: 01/08/2019 